\title{
Detection of Toxoplasma gondii in Cerebrospinal Fluid from AIDS Patients by Polymerase Chain Reaction
}

\author{
STEPHEN F. PARMLEY ${ }^{1}$ FRANK D. GOEBEL, $\dagger$ AND JACK S. REMINGTON ${ }^{1,2 *}$ \\ Department of Immunology and Infectious Diseases, Research Institute, \\ 860 Bryant Street, Palo Alto, California 94301, ${ }^{1}$ and Division of Infectious Diseases, \\ Stanford University School of Medicine, Stanford, California $94305^{2}$
}

Received 26 May 1992/Accepted 4 August 1992

\begin{abstract}
The polymerase chain reaction (PCR) was used to detect Toxoplasma gondii DNA in cerebrospinal fluid (CSF) from 14 patients with AIDS by amplification of the repetitive B1 gene. Positive PCRs were obtained in CSF from four of nine patients with toxoplasmic encephalitis. CSF samples from five control patients were negative for $T$. gondii DNA by PCR.
\end{abstract}

Toxoplasmosis is one of the most common opportunistic infection in patients with AIDS and results in a life-threatening encephalitis (5). A definitive diagnosis is rarely accomplished without a brain biopsy. Since serologic tests have not proven useful for diagnosis of the disease in patients with AIDS, methods which allow detection of the parasite in tissue and body fluids are more useful. One method that has been used successfully for the detection toxoplasma DNA in clinical specimens is the polymerase chain reaction (PCR) (1). Toxoplasma infection has been diagnosed correctly by PCR of amniotic fluid and blood $(2,3,9)$. PCR analysis of cerebrospinal fluid (CSF) has been successful in diagnosing herpes simplex encephalitis and parasitic treponemes $(4,7)$ as well as toxoplasma infection $(6,8)$. In the study by van de Ven and colleagues (8), a positive PCR was obtained by using CSF from an infant congenitally infected with Toxoplasma gondii, but not with CSF from an adult patient diagnosed with toxoplasmic encephalitis (TE) by other means. In the study by Lebech and colleagues (6), positive PCRs were observed with CSF from two patients with AIDS and acute cerebral toxoplasmosis.

We used the PCR assay on the basis of amplification of the 35 -fold repetitive B1 gene of $T$. gondii. In this study, CSF specimens from 14 patients with AIDS were analyzed by PCR. Nine of the 14 patients were diagnosed as having TE on the basis of the results of computed tomography scans, clinical signs of toxoplasmosis, seropositivity for $T$. gondii, and response to antitoxoplasma therapy. CSF samples were obtained from the remaining five patients for other reasons and did not show any signs of toxoplasma infection. These five CSF specimens were used as controls. CSF specimens from all of the patients were frozen immediately after collection at the Medical Poliklinik, University of Munich, Munich, Germany, and were shipped on dry ice to the Research Institute in Palo Alto, Calif.

To prepare the specimens for amplification, the CSF was thawed on ice and centrifuged at $10,000 \times g$ at $4^{\circ} \mathrm{C}$ to pellet the cells. Cell pellets were resuspended in $150 \mu \mathrm{l}$ of sterile distilled water and were heated to $94^{\circ} \mathrm{C}$ for $10 \mathrm{~min}$ to lyse the cells. The lysed samples were directly assayed by PCR amplification of the B1 target gene of $T$. gondii as described

\footnotetext{
* Corresponding author.

$\dagger$ Present address: Medical Poliklinik, University München, 8000 Munich 2, Germany.
}

previously (3). Briefly, $50 \mu \mathrm{l}$ of each lysed specimen was analyzed by PCR in a final volume of $100 \mu$ l containing 10 $\mathrm{mM}$ Tris- $\mathrm{HCl}$ (pH 8.3); $50 \mathrm{mM} \mathrm{KCl} ; 2.5 \mathrm{mM} \mathrm{MgCl}$; $0.01 \%$ gelatin; $200 \mu \mathrm{M}$ (each) dATP, dGTP, dCTP, and dTTP; 100 pmol of each B1 oligonucleotide primer 1 and 4 (1); and 2.5 U of Taq DNA polymerase (Perkin-Elmer Cetus). Amplification was carried out for 55 cycles in a PTC-100 programmable thermal controller (MJ Research). Each cycle consisted of $1 \mathrm{~min}$ of denaturation at $94^{\circ} \mathrm{C}, 1 \mathrm{~min}$ of annealing at $50^{\circ} \mathrm{C}$, and 2 min of extension at $72^{\circ} \mathrm{C}$. About $10 \mu \mathrm{l}$ of the amplified DNA samples was analyzed by agarose gel electrophoresis, and the 110 -bp products were visualized by staining with ethidium bromide. About $50 \mu$ l of the amplified DNA samples was denatured by treatment with $0.4 \mathrm{~N}$ $\mathrm{NaOH}$, boiled, neutralized, and transferred to nitrocellulose in a slot blot apparatus (Bethesda Research Laboratories); and the DNA was covalently bound to the membrane by baking at $80^{\circ} \mathrm{C}$ for $1 \mathrm{~h}$. Specific amplification of the B1 target gene was detected by hybridization of the blots with radioactively labeled oligonucleotide 3 as described previously (1). Positive control PCRs performed on mock specimens containing approximately five tachyzoites and negative control reactions with no target DNA were included with each set of CSF specimens tested. Previous experiments have shown that the B1 gene amplification procedure is sensitive enough to detect a single isolated parasite and as few as 10 parasites in a background of 100,000 leukocytes (1). CSF specimens were analyzed in duplicate. Those specimens that yielded a positive signal in only one of the two assays were analyzed a third time by B1 amplification of the remaining 50 $\mu l$ of cell lysate. Specimens that yielded a specific positive signal in at least two assays were considered positive. All specimens were coded in order to perform the PCR analysis in a blinded manner. Special care was taken to avoid cross-contamination of samples, including the use of positive displacement pipettes. In a separate series of experiments, PCR amplification with the B1 primers was negative when performed on numerous other opportunistic pathogens, including Aspergillus fumigatus, Candida albicans, Cryptococcus neoformans, and Absidia spp. (2a). In addition, PCR was negative when performed on over 40 CSF specimens from patients who were seronegative for toxoplasma antibodies (data not shown).

The results of the PCR analysis of the CSF from the 14 patients with AIDS are summarized in Table 1, which also provides relevant clinical information for each patient. $\mathrm{Pa}$ 


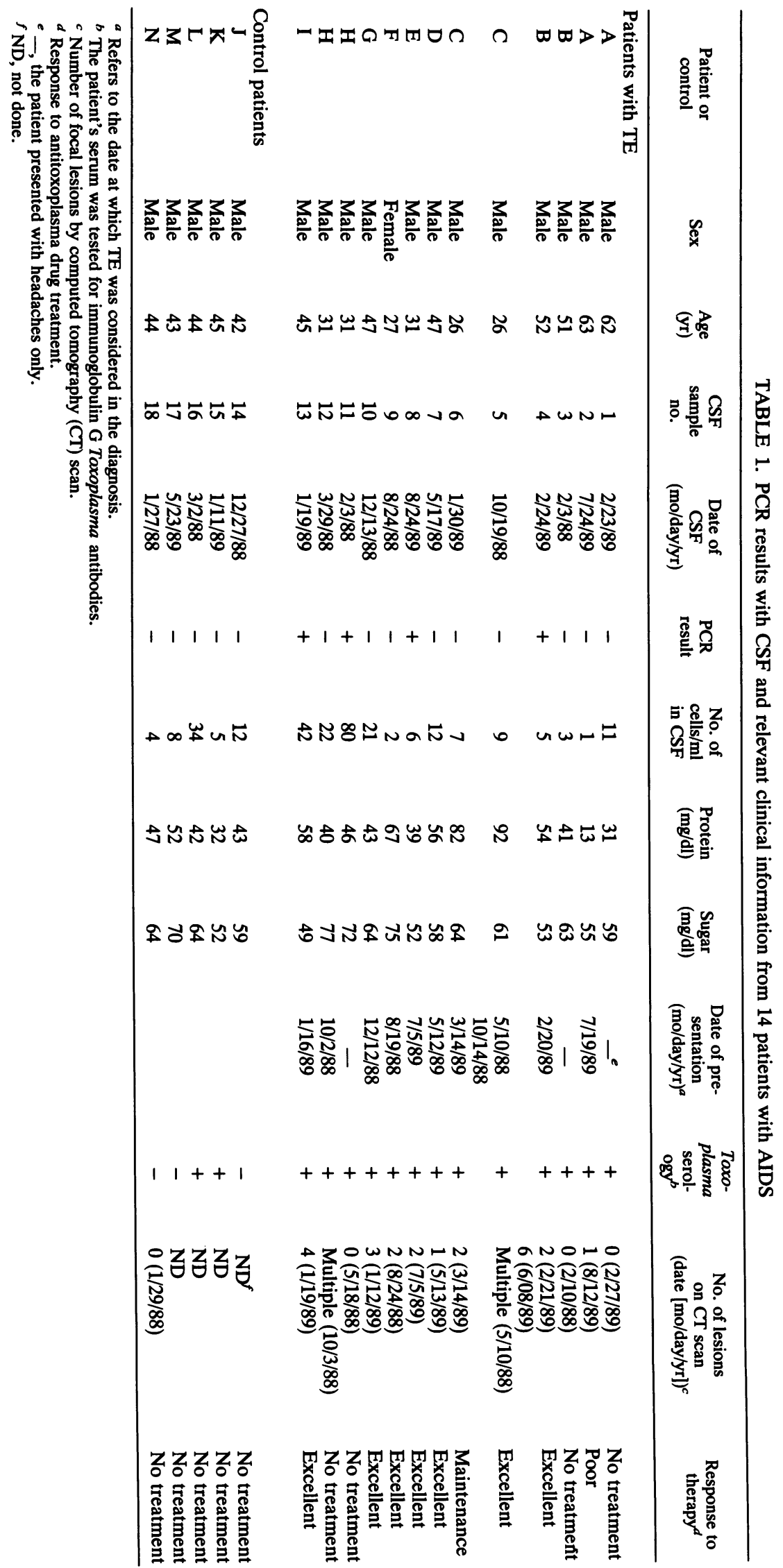


tients A to I were diagnosed with TE on the basis of clinical signs. Two separate CSF samples were obtained from patients $\mathrm{A}, \mathrm{B}, \mathrm{C}$, and $\mathrm{H}$ at intervals of $5,13,3$, and 2 months apart, respectively. Specimens $4,8,11$, and 13 were positive by the PCR assay; these were from patients $B, E, H$, and I, respectively. The remaining $14 \mathrm{CSF}$ samples did not yield a positive signal by the PCR assay, including the specimens from the five control patients and one CSF sample that was obtained from patient B 13 months prior to the development of clinical signs of TE. Patients A and B died, and autopsies revealed disseminated toxoplasma infections in both cases. In summary, there were no false-positive reactions in the five control specimens, and four samples from nine patients with TE were positive by PCR. Thus, PCR detected TE in $44 \%$ of our patients.

These results demonstrate that PCR analysis of CSF from patients with suspect TE is a promising method for diagnosing $T$. gondii infection by directly detecting parasite DNA. Although the results were in a relatively small sample of patients and were not positive in all CSF specimens obtained from those patients that were confirmed by clinical diagnosis to have TE, the PCR is at least as sensitive as existing laboratory methods and the results can be obtained much more rapidly.

This work was supported by NIH grant A104714; the University of California's University wide AIDS Research program (grant R91PAM007), and a grant from the MacArthur Foundation (University of Stanford program).

\section{REFERENCES}

1. Burg, J. L., C. M. Grover, P. Pouletty, and J. C. Boothroyd. 1989. Direct and sensitive detection of a pathogenic protozoan, Toxo- plasma gondii, by polymerase chain reaction. J. Clin. Microbiol. 27:1787-1792.

2. Christina, N., F. Derouin, H. Pelloux, R. Pierce, M. F. CesbronDelauw, and P. Ambroise-Thomas. 1992. Polymerase chain reaction (PCR) detection of T. gondii in AIDS patients using the repetitive sequence TGR1 $1_{E}$. Pathol. Biol. 40:52-55. (In French.)

2a.Grover, C. M., and J. C. Boothroyd. Unpublished data.

3. Grover, C. M., P. Thulliez, J. S. Remington, and J. C. Boothroyd. 1990. Rapid prenatal diagnosis of congenital toxoplasmosis from amniotic fluid by polymerase chain reaction. J. Clin. Microbiol. 28:2297-2301.

4. Hay, P. E., J. R. Clarke, R. A. Strugnell, D. Taylor-Robinson, and D. Goldmeier. 1990. Use of the polymerase chain reaction to detect DNA sequences specific to pathogenic treponemes in cerebrospinal fluid. FEMS Microbiol. Lett. 68:233-238.

5. Israelski, D. M., and J. S. Remington. 1992. AIDS-associated toxoplasmosis, p. 319-345. In M. A. Sande and P. A. Volberding (ed.). The medical management of AIDS, 3rd ed. The W. B. Saunders Co., Philadelphia.

6. Lebech, M., A. Lebech, S. Nelsing, J. Vuust, L. Mathiesen, and E. Petersen. 1992. Detection of Toxoplasma gondii by polymerase chain reaction in cerebrospinal fluid from AIDS patients with cerebral toxoplasmosis. J. Infect. Dis. 165:982-983.

7. Rowley, A. H., R. J. Whitley, F. D. Lakeman, and S. M. Wolinsky. 1990. Rapid detection of herpes-simplex-virus in cerebrospinal fluid of patients with herpes simplex encephalitis. Lancet 335:440-441.

8. van de Ven, E., W. Melchers, J. Galama, W. Camps, and J. Muewissen. 1991. Identification of Toxoplasma gondii infections by B1 gene amplification. J. Clin. Microbiol. 29:2120-2124.

9. Weiss, L. M., S. A. Udem, M. Salgo, H. B. Tanowitz, and M. Wittner. 1991. Sensitive and specific detection of Toxoplasma DNA in an experimental murine model: use of $T$. gondii-specific cDNA and the polymerase chain reaction. J. Infect. Dis. 193: 180-186. 